\title{
Analysis of Causes of Hepatic Dysfunction in Obstetric Patients in India: A Systematic Review
}

\author{
Armin Ahmed ${ }^{1} \odot$, Sulekha Saxena ${ }^{\odot} \odot$ Amita Pandey $^{3} \odot$ Prabhakar Mishra $^{4} \odot$, Afzal Azim $^{5} \odot$
}

\begin{abstract}
Background: Epidemiology of liver disease in obstetric patients shows geographical variation depending upon the prevalence of preeclampsia, viral hepatitis, and tropical vector-borne diseases like malaria, leptospirosis, etc. We undertook the current systematic review to analyze the causes of hepatic dysfunction in obstetric patients in India and identify the gaps in the literature and reporting.

Materials and methods: We did a systematic review of studies reporting the causes of hepatic dysfunction in obstetric patients in India. A methodological quality assessment was done using a five-point questionnaire.

Results: A total of 21 studies qualified for evaluation. The rate of hepatic dysfunction among obstetric patients in India ranged from 0.15 to $3.3 \%$ with a mean and median rate of 1.49 and $0.93 \%$, respectively. Preeclampsia/HELLP (mean $=36.0 \%$, median $=31.4 \%$, range: $3.6-83.8 \%$ ) and viral hepatitis (mean $=34.1 \%$, median $=35.5 \%$, range: $5.1-61.8 \%$ ) were the commonest causes of hepatic dysfunction. Other causes were intrahepatic cholestasis of pregnancy, acute fatty liver of pregnancy, tropical fever (malaria, leptospirosis, dengue, scrub typhus), etc. Maternal mortality ranged from 1.4 to $40 \%$ (mean $=12.6 \%$, median $=10.0 \%)$ and perinatal mortality was between 16.4 and $38.70 \%($ mean $=31.75 \%$, median $=35.5 \%$ ).

Conclusion: There is moderate quality evidence to show that preeclampsia/HELLP and viral hepatitis are the commonest causes of hepatic dysfunction in obstetric patients in India.

Keywords: Hepatic dysfunction, Obstetric patients, Preeclampsia, Viral hepatitis.

Indian Journal of Critical Care Medicine (2022): 10.5005/jp-journals-10071-24083
\end{abstract}

\section{INTRODUCTION}

Reducing maternal mortality across the globe is one of the priorities of sustainable development goals to be achieved by $2030{ }^{1}$ According to the recent (2016-18) statistics reported by the Ministry of Health and Family Welfare, the maternal mortality ratio (MMR) of India is 113 per 100,000 live births. There is significant inequity within the country as states like Assam and Uttar Pradesh have an MMR of 215 and 197 per 100,000 live births, while states like Kerala and Maharashtra have an MMR as low as 43 and 46 per 100,000 live births, respectively. ${ }^{2}$ With developing countries carrying a significant burden of maternal mortality, there is a need to focus on local epidemiology and develop protocolized care for obstetric patients based on regional guidelines. ${ }^{3}$

Among the various diseases causing maternal mortality and morbidity, liver disease can be challenging for clinicians. In 2019, a position statement was given by The Indian National Association for the Study of the Liver in collaboration with the Federation of Obstetric and Gynaecological Societies of India for the management of liver disease in pregnancy, but Indian epidemiological data have never been systematically reviewed in this field. ${ }^{4}$

Hepatic dysfunction in pregnancy can occur due to diverse etiologies and shows geographical variation. Broadly, it can be classified as liver diseases unique to pregnancy, liver diseases coincidental with pregnancy, and pregnancy in a patient with preexisting liver disease. ${ }^{5}$ Indian epidemiology is unique due to the high prevalence of viral hepatitis and other tropical illnesses that can present with jaundice and encephalopathy syndrome, thus mimicking acute liver failure. ${ }^{6}$ Differentiation of these causes is essential as diseases like malaria, leptospirosis, scrub typhus, etc., have specific treatment and are completely curable. Deepak

\footnotetext{
1,2 Department of Critical Care Medicine, King George Medical University, Lucknow, Uttar Pradesh, India

${ }^{3}$ Department of Obstetrics and Gynaecology, King George Medical University, Lucknow, Uttar Pradesh, India

${ }^{4}$ Department of Biostatistics, Sanjay Gandhi Postgraduate Institute of Medical Sciences, Lucknow, Uttar Pradesh, India

${ }^{5}$ Department of Critical Care Medicine, Sanjay Gandhi Postgraduate Institute of Medical Sciences, Lucknow, Uttar Pradesh, India

Corresponding Author: Afzal Azim, Department of Critical Care Medicine, Sanjay Gandhi Postgraduate Institute of Medical Sciences, Lucknow, Uttar Pradesh, India, Phone: +91 8004904730, e-mail: afzalazim38@gmail.com

How to cite this article: Ahmed A, Saxena S, Pandey A, Mishra P, Azim A. Analysis of Causes of Hepatic Dysfunction in Obstetric Patients in India: A Systematic Review. Indian J Crit Care Med 2022;26(1):114-122. Source of support: Nil

Conflict of interest: None
}

and Patel studied acute liver failure in 28 patients admitted over a two-year period. Patients were classified as acute liver failure due to acute viral hepatitis (ALF-AVH) vs acute liver failure due to infectious disease (ALF-ID). Mortality was lower in ALF-ID (25\%) patients as compared to ALF-AVH (50\%). Causes of ALF-ID in the study group were typhoid fever, falciparum malaria, rickettsial infection, dengue fever, leptospirosis, amoebic liver abscess, and hemophagocytosis. ${ }^{7}$

Infectious causes of hepatic dysfunction also need to be differentiated from pregnancy-specific causes of hepatic dysfunction, as termination of pregnancy can help improve

(c) The Author(s). 2022 Open Access This article is distributed under the terms of the Creative Commons Attribution 4.0 International License (https://creativecommons. org/licenses/by-nc/4.0/), which permits unrestricted use, distribution, and non-commercial reproduction in any medium, provided you give appropriate credit to the original author(s) and the source, provide a link to the Creative Commons license, and indicate if changes were made. The Creative Commons Public Domain Dedication waiver (http://creativecommons.org/publicdomain/zero/1.0/) applies to the data made available in this article, unless otherwise stated. 
maternal outcomes in some of the pregnancy-specific causes of hepatic dysfunction. Among the five pregnancy-specific diseases causing hepatic dysfunction, three (preeclampsia, HELLP, and acute fatty liver of pregnancy) are associated with more severe forms of liver disease and, together, termed as pregnancy-associated acute liver disease (PAALD). In a study including 87 pregnant patients with hepatic dysfunction, Devarbhavi et al. compared 46 PAALD patients with 41 patients of viral hepatitis. Mortality was 41 and $7.5 \%$ in the two groups, respectively. The authors reported the presence of ascites and hypertension as factors associated with a diagnosis of PAALD, triggering prompt delivery. ${ }^{8}$

Systematic reviews are a powerful tool to summarize available data in a particular field. The aim of the study was to analyze the causes of hepatic dysfunction in obstetric patients in the country. We undertook the current systematic review with the following objectives:

- To estimate the rate of hepatic dysfunction in obstetric patients in India

- To identify the causes of hepatic dysfunction in obstetric patients in India

- To identify the gaps in the literature and reporting of liver diseases in obstetric patients in India

\section{Materials and Methods}

\section{Study Selection}

Studies reporting hepatic dysfunction and its causes in obstetric patients in India were considered eligible for analysis. An obstetric patient was defined as a pregnant woman or a woman within 42 days of delivery. Hepatic dysfunction was defined as clinical evidence of jaundice and/or total bilirubin of more than $2 \mathrm{mg} / \mathrm{dL}$ along with elevated liver enzymes above the physiological range. To generate more stable and reliable information, we excluded the studies with less than 25 patients. This cutoff was arbitrary. We further excluded those studies that did not include at least four of the following causes: viral hepatitis, preeclampsia/eclampsia, HELLP syndrome, acute fatty liver of pregnancy, intrahepatic cholestasis of pregnancy, tropical fever, hemolytic anemia, and chronic liver disease.

\section{Literature Search}

A literature search was done in PubMed/Medline/Scopus/Google Scholar for original research articles using the terminology "Hepatic dysfunction in pregnancy," "Jaundice in pregnancy," "Liver disease in pregnancy," "Hepatic dysfunction in obstetric patients," "Jaundice in obstetric patients," "Liver disease in obstetric patients." We included all case-control, cross-sectional, and cohort studies published in the English language between January 1, 2011, and December 31, 2020 (10 years). The bibliography of the relevant research articles was also searched for other suitable studies, and papers citing included studies were also reviewed. The title and abstract of documents found by the literature search were reviewed, and unsuitable manuscripts or duplicate results were excluded. The remaining papers were reviewed independently by two authors, and disagreements were resolved by consensus. Studies done in other geographical areas besides India were excluded. We also excluded the studies that only dealt with hepatitis in pregnancy (Flowchart 1).

\section{Study Quality Assessment}

A methodological quality assessment of the eligible studies was done to know the probability of bias in the information retrieved. Risk of bias assessment in epidemiological studies can be done using a standard assessment tool or by using a customized bias assessment tool developed specifically for the review. We chose the latter approach and developed our own questionnaire to assess the study quality after reviewing the literature for a bias assessment in epidemiological studies. ${ }^{9}$ The studies were assessed with a 5-point questionnaire using the following attributes: (1) Reporting of well-defined appropriate patient recruitment criteria; (2) Use of robust approach to ascertain the cause of hepatic dysfunction; (3) Identification of all common causes of hepatic dysfunction in pregnancy to reduce the risk of misclassification of cause of hepatic dysfunction; (4) Sufficient number of patients having the cause of hepatic dysfunction ascertained (unclassified 10\%); and (5) Reporting of the causes of maternal mortality in patients with hepatic dysfunction. Studies scoring two or more were included for analysis. A score of 5 was considered high-quality evidence, while a score of 3 or 4 was considered moderate-quality evidence. Scores less than 3 were considered poor quality evidence.

\section{Data Extraction}

Data collection was done from the studies qualifying for analysis using a data extraction form. Information was retrieved from the full text of the studies under the following heading: the objective of the study, name of the first author, year, place, and duration of the study.

Flowchart 1: PRISMA flow diagram

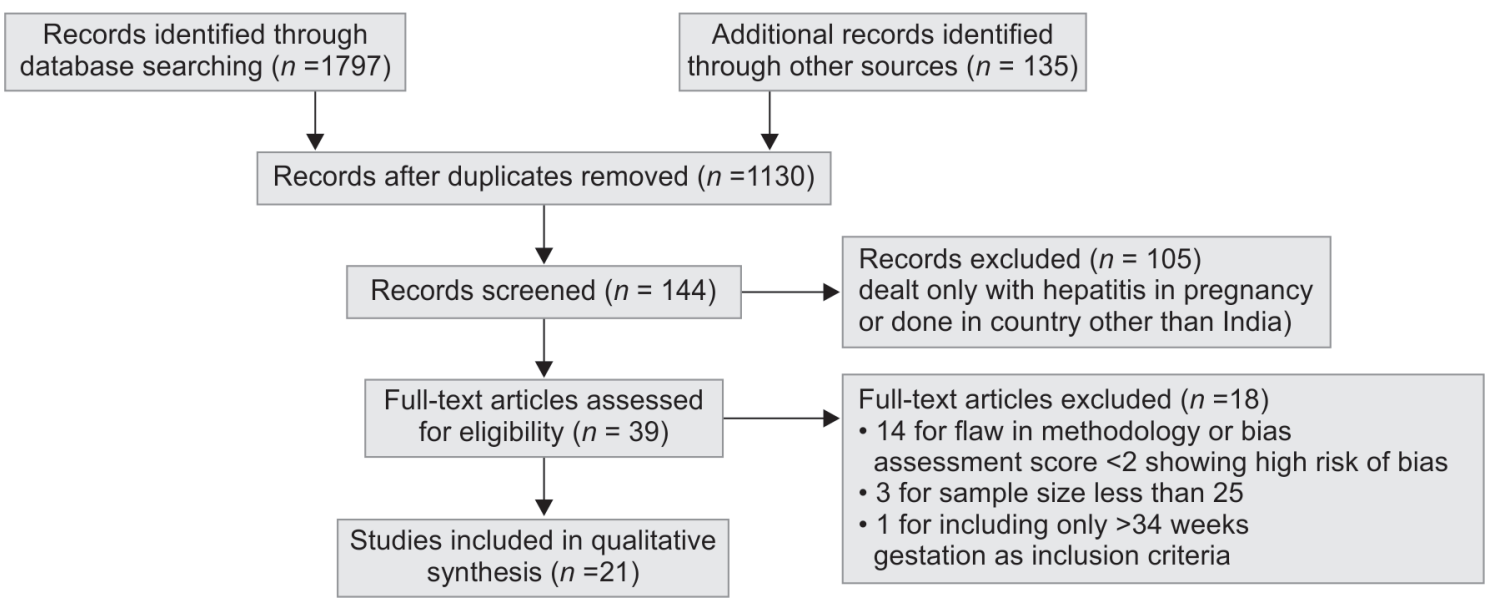


Number and location of centers, study design, inclusion and exclusion criteria, rate of hepatic dysfunction, the total number of cases, maternal mortality, perinatal mortality, causes of hepatic dysfunction, and causes of maternal death were noted.

\section{Statistical Analysis}

We used Prism v 5.0 (Carlsbad, California, USA) and MedCalc Software for statistical analysis. Categorical variables were represented as frequencies and percentages. Causes of maternal mortality and hepatic dysfunction in pregnancy were represented as bar graphs.

\section{Results}

Our search resulted in the identification of 1,797 records. After excluding the articles which did not qualify our study selection criteria, the full text of 39 articles was read for eligibility. Another 18 studies were excluded due to poor methodology, small sample size, or inclusion of only a subgroup of pregnant patients (see Flowchart 1). A total of 21 studies were included for the final analysis. The methodological quality assessment showed deficiencies in several areas of methodology. Sixteen studies were of moderate quality with a score of 3 (eight studies) or 4 (eight studies). Two studies had a score of 5 , while three studies had a score of 2 (Table 1). ${ }^{10-30}$

\section{Study Characteristics}

Among the 21 studies included, five were conducted to study the clinical spectrum, causes, and outcome of hepatic dysfunction in pregnancy, while 16 were done to investigate the fetomaternal outcome of jaundice during pregnancy. There were five retrospective studies and 16 prospective studies. All were single-center studies conducted in government hospitals except for five studies done in private hospitals. The duration of the study was from 6 to 30 months. The sample size ranged from 30 to 300 patients, with the largest sample from the government medical college of Bhopal (Madhya Pradesh). Maximum studies were from Mumbai, where three studies were conducted (Fig. 1). Most of the centers were in the northern and southern parts of the country. There are limited data from the eastern and central parts of the country. Fourteen studies included only admitted patients, whereas seven studies included both admitted as well as outpatients (Table 2). ${ }^{10-30}$

\section{Rate of Hepatic Dysfunction and Maternal Mortality}

Rate of hepatic dysfunction among pregnant women ranged from 0.15 to $3.3 \%$ with a mean and median rate of 1.49 and $0.93 \%$. Similarly, maternal mortality ranged from 1.4 to $40 \%$ (mean $=12.6 \%$, median $=10.0 \%$ ) while perinatal mortality was between 16.4 and $38.70 \%($ mean $=31.75 \%$, median $=35.5 \%)($ Table 2$) .^{10-30}$

\section{Causes of Hepatic Dysfunction during Pregnancy}

Preeclampsia and HELLP were the commonest causes of hepatic dysfunction $($ mean $=36.0 \%$, median $=31.4 \%$, range: $3.6-83.8 \%$ ) followed by viral hepatitis ( mean $=34.1 \%$, median $=35.5 \%$, range: 5.1-61.8\%). Other causes included cholestasis of pregnancy (mean $=16.9 \%$, median $=15.0 \%$, range: $1.2-54.9 \%)$ followed by acute fatty liver of pregnancy $($ mean $=2.6 \%$, median $=1.4 \%$, range: $0-10.4 \%)$, tropical fever $($ mean $=2.5 \%$, median $=0.8 \%$, range:

Table 1: Bias assessment

\begin{tabular}{|c|c|c|c|c|c|c|}
\hline Authors & $\begin{array}{l}\text { Appropriate eligibility } \\
\text { and recruitment of } \\
\text { patients clearly defined }\end{array}$ & $\begin{array}{l}\text { Confirmation of the } \\
\text { cause of hepatic } \\
\text { dysfunction with } \\
\text { laboratory or autopsy }\end{array}$ & $\begin{array}{c}\text { All common causes } \\
\text { of hepatic } \\
\text { dysfunction in } \\
\text { pregnancy included }\end{array}$ & $\begin{array}{c}\text { Unclassified causes } \\
\text { of hepatic } \\
\text { dysfunction } 10 \%\end{array}$ & $\begin{array}{c}\text { Causes of } \\
\text { maternal } \\
\text { mortality given }\end{array}$ & Total score \\
\hline Tiwari et al. ${ }^{10}$ & $x$ & $x$ & 0 & $\mathrm{O}$ & 0 & 3 \\
\hline Changede et al. ${ }^{11}$ & $x$ & $x$ & $\mathrm{O}$ & $\mathrm{O}$ & $\mathrm{O}$ & 3 \\
\hline Bhalla et al. ${ }^{12}$ & $\mathrm{O}$ & $x$ & $\mathrm{O}$ & $\mathrm{O}$ & $\mathrm{O}$ & 4 \\
\hline Padh et al. ${ }^{13}$ & $x$ & $\mathrm{O}$ & $\mathrm{O}$ & $\mathrm{O}$ & $x$ & 3 \\
\hline Negi et al. ${ }^{14}$ & $\mathrm{O}$ & $\mathrm{O}$ & $\mathrm{O}$ & $\mathrm{O}$ & $\mathrm{O}$ & 5 \\
\hline Agarwal et al. ${ }^{15}$ & $\mathrm{O}$ & $x$ & $\mathrm{O}$ & $\mathrm{O}$ & $\mathrm{O}$ & 4 \\
\hline Devi and Bhavani ${ }^{16}$ & $x$ & $x$ & $\mathrm{O}$ & $\mathrm{O}$ & $\mathrm{O}$ & 3 \\
\hline Choudhary et al. ${ }^{17}$ & $x$ & $\mathrm{O}$ & $\mathrm{O}$ & $\mathrm{O}$ & $\mathrm{O}$ & 4 \\
\hline Kohli et al. ${ }^{18}$ & $x$ & $\mathrm{O}$ & $\mathrm{O}$ & $\mathrm{O}$ & $\mathrm{O}$ & 4 \\
\hline Sunanda et al. ${ }^{19}$ & $\mathrm{O}$ & $x$ & $\mathrm{O}$ & $\mathrm{O}$ & $\mathrm{O}$ & 4 \\
\hline Suresh et al. ${ }^{20}$ & $x$ & $x$ & $\mathrm{O}$ & $\mathrm{O}$ & $\mathrm{O}$ & 3 \\
\hline Tiwari et al. ${ }^{21}$ & $x$ & $x$ & $\mathrm{O}$ & $\mathrm{O}$ & $x$ & 2 \\
\hline Solanke et al. ${ }^{22}$ & $x$ & $\mathrm{O}$ & $\mathrm{O}$ & $\mathrm{O}$ & $\mathrm{O}$ & 4 \\
\hline Sharma et al. ${ }^{23}$ & $x$ & $x$ & $\mathrm{O}$ & $\mathrm{O}$ & $\mathrm{O}$ & 3 \\
\hline Mitta and $\mathrm{Rao}^{24}$ & $x$ & $\mathrm{O}$ & $\mathrm{O}$ & 0 & $\mathrm{O}$ & 4 \\
\hline $\begin{array}{l}\text { Krishnamoorthy } \\
\text { and Murugesan } 25\end{array}$ & $x$ & $x$ & $\mathrm{O}$ & $\mathrm{O}$ & $\mathrm{O}$ & 3 \\
\hline Mishra et al. ${ }^{26}$ & $\mathrm{O}$ & $\mathrm{O}$ & $\mathrm{O}$ & $\mathrm{O}$ & $\mathrm{O}$ & 5 \\
\hline $\begin{array}{l}\text { Satia and } \\
\text { Jandhyala }\end{array}$ & $x$ & $x$ & $\mathrm{O}$ & $\mathrm{O}$ & $\mathrm{O}$ & 3 \\
\hline Dsouza et al. ${ }^{28}$ & $x$ & $x$ & $\mathrm{O}$ & $\mathrm{O}$ & $x$ & 2 \\
\hline Singh et al. ${ }^{29}$ & $x$ & $x$ & $x$ & $\mathrm{O}$ & $\mathrm{O}$ & 2 \\
\hline Nath et al. ${ }^{30}$ & $x$ & $\mathrm{O}$ & 0 & $\mathrm{O}$ & 0 & 4 \\
\hline
\end{tabular}

$\mathrm{X}$, not answered; O, answered 


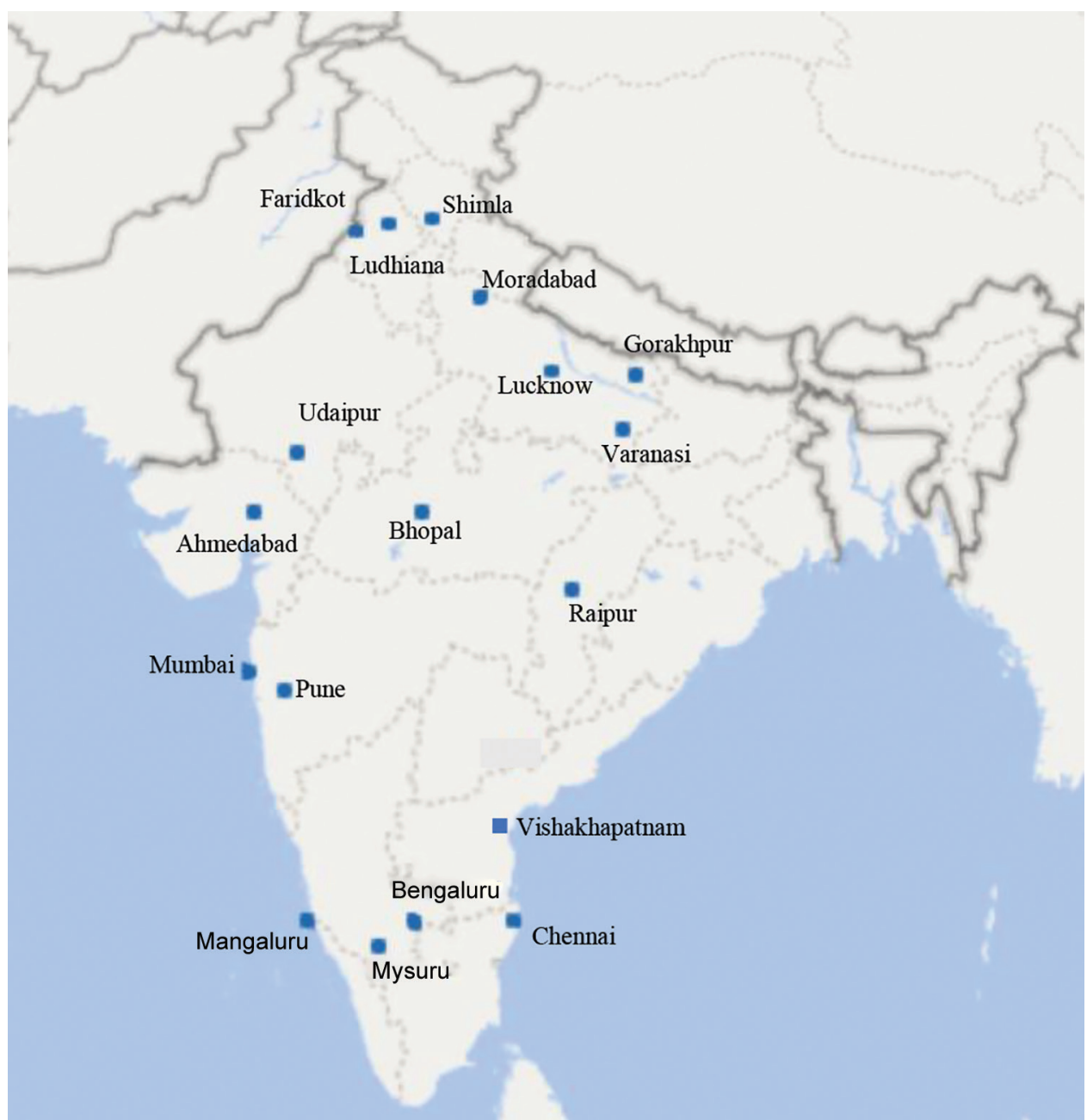

Fig. 1: Location of hospitals where studies were done

Table 2: Characteristics of studies included for the analysis of hepatic dysfunction in obstetric patients in the Indian subcontinent

\begin{tabular}{|c|c|c|c|c|c|c|c|c|c|c|c|}
\hline Author & $\begin{array}{l}\text { Study } \\
\text { design }\end{array}$ & $\begin{array}{l}\text { No of } \\
\text { centers }\end{array}$ & $\begin{array}{c}\text { Government/ } \\
\text { private }\end{array}$ & Location & $\begin{array}{c}\text { Study } \\
\text { duration } \\
\text { (years) }\end{array}$ & $\begin{array}{l}\text { ANCl } \\
\text { PNC/ } \\
\text { both }\end{array}$ & $\begin{array}{c}\text { Outpatient/ } \\
\text { admitted/ } \\
\text { both }\end{array}$ & $\begin{array}{c}\text { Rate (hepatic } \\
\text { dysfunction) } \\
\text { (\%) }\end{array}$ & $\begin{array}{c}\text { Maternal } \\
\text { mortality } \\
\text { (\%) }\end{array}$ & $\begin{array}{l}\text { Perinatal } \\
\text { mortality } \\
\text { (\%) }\end{array}$ & $\begin{array}{l}\text { Total } \\
\text { cases }\end{array}$ \\
\hline Tiwari et al. ${ }^{10}$ & $P$ & 1 & G & Bhopal & 1 & ANC & Admitted & NA & 4.3 & 31 & 300 \\
\hline $\begin{array}{l}\text { Changede } \\
\text { et al. }^{11}\end{array}$ & $\mathrm{R}$ & 1 & G & Mumbai & 1 & ANC & Admitted & NA & 40 & 37 & 43 \\
\hline Bhalla et al. ${ }^{12}$ & $P$ & 1 & G & Faridkot & 1 & ANC & Both & 3.1 & 5.9 & NA & 118 \\
\hline Padh et al. ${ }^{13}$ & $P$ & 1 & G & Ahmedabad & 3.5 & ANC & Admitted & 0.32 & 12.85 & 35.71 & 70 \\
\hline Negi et al. ${ }^{14}$ & $P$ & 1 & G & Shimla & 1 & ANC & Both & 3 & 7.14 & NA & 126 \\
\hline $\begin{array}{l}\text { Agarwal } \\
\text { et al. }{ }^{15}\end{array}$ & $P$ & 1 & G & Lucknow & 1 & ANC & Admitted & 1.2 & 39.3 & 37 & 122 \\
\hline $\begin{array}{l}\text { Devi and } \\
\text { Bhavani }^{16}\end{array}$ & $P$ & 1 & G & $\begin{array}{l}\text { Vishakha } \\
\text { patnam }\end{array}$ & 2 & ANC & Admitted & 0.72 & 12.74 & 35.71 & 102 \\
\hline $\begin{array}{l}\text { Choudhary } \\
\text { et al. } .^{17}\end{array}$ & $P$ & 1 & G & Udaipur & 1 & ANC & Admitted & 0.28 & 18.96 & 38 & 58 \\
\hline Kohli et al. ${ }^{18}$ & $\mathrm{R}$ & 1 & G & Pune & 2 & ANC & Admitted & 2.9 & 1.37 & NA & 146 \\
\hline $\begin{array}{l}\text { Sunanda } \\
\text { et al. } .^{19}\end{array}$ & $P$ & 1 & G & Bengaluru & 1.5 & ANC & Both & 0.15 & 13 & 25.8 & 31 \\
\hline Suresh et al. ${ }^{20}$ & $\mathrm{P}$ & 1 & G & Mysore & 2 & ANC & Both & 3.2 & 2.5 & NA & 197 \\
\hline
\end{tabular}


Table 2: (Contd...)

\begin{tabular}{|c|c|c|c|c|c|c|c|c|c|c|c|}
\hline Author & $\begin{array}{l}\text { Study } \\
\text { design }\end{array}$ & $\begin{array}{l}\text { No of } \\
\text { centers }\end{array}$ & $\begin{array}{c}\text { Government/ } \\
\text { private }\end{array}$ & Location & $\begin{array}{l}\text { Study } \\
\text { duration } \\
\text { (years) }\end{array}$ & $\begin{array}{l}\text { ANCl } \\
\text { PNCl } \\
\text { both }\end{array}$ & $\begin{array}{c}\text { Outpatient/ } \\
\text { admitted/ } \\
\text { both }\end{array}$ & $\begin{array}{c}\text { Rate (hepatic } \\
\text { dysfunction) } \\
\text { (\%) }\end{array}$ & $\begin{array}{l}\text { Maternal } \\
\text { mortality } \\
\text { (\%) }\end{array}$ & $\begin{array}{l}\text { Perinatal } \\
\text { mortality } \\
\text { (\%) }\end{array}$ & $\begin{array}{l}\text { Total } \\
\text { cases }\end{array}$ \\
\hline Tiwari et al. ${ }^{21}$ & $P$ & 1 & $\mathrm{G}$ & Gorakhpur & 1 & ANC & Both & 2.37 & 13 & 29.17 & 214 \\
\hline Solanki et al. ${ }^{22}$ & $P$ & 1 & G & Mumbai & 2 & ANC & Both & NA & 24.2 & 38.7 & 103 \\
\hline $\begin{array}{l}\text { Sharma } \\
\text { et al. }{ }^{23}\end{array}$ & $P$ & 1 & $\operatorname{Pr}$ & Bhopal & 1 & ANC & Admitted & NA & 3.3 & NA & 30 \\
\hline $\begin{array}{l}\text { Mitta and } \\
\text { Rao }^{24}\end{array}$ & $P$ & 1 & $\operatorname{Pr}$ & Mangaluru & 2 & ANC & Admitted & 0.31 & 4.76 & 30.76 & 42 \\
\hline $\begin{array}{l}\text { Krishna } \\
\text { moorthy and } \\
\text { Murugesan }^{25}\end{array}$ & $P$ & 1 & G & Chennai & 1 & ANC & Admitted & 0.29 & 7.8 & 35.5 & 51 \\
\hline Mishra et al. ${ }^{26}$ & $P$ & 1 & G & Raipur & 1.5 & ANC & Admitted & 0.9 & 4 & NA & 80 \\
\hline $\begin{array}{l}\text { Satia and } \\
\text { Jandhyala }\end{array}$ & $\mathrm{R}$ & 1 & G & Mumbai & 1 & both & Admitted & 0.81 & 22 & 22 & 55 \\
\hline Dsouza et al. ${ }^{28}$ & $\mathrm{R}$ & 1 & $\operatorname{Pr}$ & Ludhiana & 1 & ANC & Admitted & 3.3 & 1.9 & NA & 51 \\
\hline Singh et al. ${ }^{29}$ & $\mathrm{R}$ & 1 & G & Varanasi & 0.5 & ANC & Admitted & NA & 15.3 & NA & 78 \\
\hline Nath et al. ${ }^{30}$ & $\mathrm{P}$ & 1 & $\operatorname{Pr}$ & Moradabad & 3 & ANC & Both & 0.95 & 10 & 16.4 & 100 \\
\hline
\end{tabular}

$\mathrm{R}$, retrospective; P, prospective; G, government hospital; Pr, private hospital; ANC, antenatal case; PNC, postnatal case; NA, not available

Table 3: Causes of hepatic dysfunction among obstetric patients in India

\begin{tabular}{|c|c|c|c|c|c|c|c|c|}
\hline Authors & $P E+H E L L P$ & AFLP & Cholestasis & Viral hepatitis & Tropical fever & $\begin{array}{c}\text { Hemolytic } \\
\text { anemia }\end{array}$ & $\begin{array}{l}\text { Undetected/ } \\
\text { others }\end{array}$ & $\begin{array}{l}\text { Total } \\
\text { cases }\end{array}$ \\
\hline Tiwari et al. ${ }^{10}$ & $69(23 \%)$ & $23(7.7 \%)$ & $14(4.7 \%)$ & $150(50 \%)$ & $0(0.0 \%)$ & $19(6.3 \%)$ & $25(8.3 \%)$ & 300 \\
\hline Changede et al. ${ }^{11}$ & $7(16.3 \%)$ & $1(2.3 \%)$ & $4(9.3 \%)$ & $21(48.8 \%)$ & $3(7.0 \%)$ & $3(7.0 \%)$ & $4(9.3 \%)$ & 43 \\
\hline Bhalla et al. ${ }^{12}$ & $73(61.9 \%)$ & $0(0.0 \%)$ & $16(13.6 \%)$ & $24(20.3 \%)$ & $0(0.0 \%)$ & $0(0.0 \%)$ & $5(4.2 \%)$ & 118 \\
\hline Padh et al. ${ }^{13}$ & $24(34.3 \%)$ & $0(0.0 \%)$ & $13(18.5 \%)$ & 27 (38.6\%) & $0(0.0 \%)$ & $2(2.9 \%)$ & $4(5.7 \%)$ & 70 \\
\hline Negi et al. ${ }^{14}$ & $33(26.2 \%)$ & $1(0.8 \%)$ & $42(33.3 \%)$ & $42(33.3 \%)$ & $1(0.8 \%)$ & $0(0.0 \%)$ & $7(5.6 \%)$ & 126 \\
\hline Agarwal et al. ${ }^{15}$ & $61(50.0 \%)$ & $11(9.0 \%)$ & $29(23.8 \%)$ & $21(17.2 \%)$ & $0(0.0 \%)$ & $0(0.0 \%)$ & $0(0.0 \%)$ & 122 \\
\hline $\begin{array}{l}\text { Devi and } \\
\text { Bhavani }{ }^{16}\end{array}$ & 32 (31.4\%) & $3(2.9 \%)$ & $4(3.9 \%)$ & $23(22.5 \%)$ & $12(11.8 \%)$ & $18(17.6 \%)$ & $10(9.8 \%)$ & 102 \\
\hline Choudhary et al. ${ }^{17}$ & $27(46.6 \%)$ & $6(10.4 \%)$ & $9(15.5 \%)$ & $11(19.0 \%)$ & $5(8.6 \%)$ & $0(0.0 \%)$ & $0(0.0 \%)$ & 58 \\
\hline Kohli et al. ${ }^{18}$ & 57 (39.0\%) & $2(1.4 \%)$ & $52(35.6 \%)$ & $33(22.6 \%)$ & $0(0.0 \%)$ & $0(0.0 \%)$ & $2(1.4 \%)$ & 146 \\
\hline Sunanda et al. ${ }^{19}$ & $10(32.3 \%)$ & $1(3.2 \%)$ & $7(22.6 \%)$ & $11(35.5 \%)$ & $0(0.0 \%)$ & $0(0.0 \%)$ & $2(6.4 \%)$ & 31 \\
\hline Suresh et al. ${ }^{20}$ & 165 (83.7\%) & $0(0.0 \%)$ & $8(4.1 \%)$ & $10(5.1 \%)$ & $2(1 \%)$ & $0(0.0 \%)$ & $12(6.1 \%)$ & 197 \\
\hline Tiwari et al. ${ }^{21}$ & $142(66.4 \%)$ & $2(0.9 \%)$ & $36(16.8 \%)$ & $23(10.7 \%)$ & $0(0.0 \%)$ & $0(0.0 \%)$ & $11(5.1 \%)$ & 214 \\
\hline Solanki et al. ${ }^{22}$ & $25(24.3 \%)$ & $2(1.9 \%)$ & $8(7.8 \%)$ & $39(37.8 \%)$ & $5(4.8 \%)$ & $0(0.0 \%)$ & $24(23.3 \%)$ & 103 \\
\hline Sharma et al. ${ }^{23}$ & $14(46.7 \%)$ & $0(0.0 \%)$ & $2(6.7 \%)$ & $14(46.7 \%)$ & $0(0.0 \%)$ & $0(0.0 \%)$ & $0(0.0 \%)$ & 30 \\
\hline Mitta and $\mathrm{Rao}^{24}$ & $9(21.4 \%)$ & $1(2.4 \%)$ & $6(14.2 \%)$ & $22(52.4 \%)$ & $2(4.8 \%)$ & $0(0.0 \%)$ & $2(4.8 \%)$ & 42 \\
\hline $\begin{array}{l}\text { Krishnamoorthy } \\
\text { and Murugesan } 25\end{array}$ & $7(13.7 \%)$ & $4(7.8 \%)$ & $3(5.9 \%)$ & $26(51.0 \%)$ & 2 (3.9\%) & $0(0.0 \%)$ & $9(17.6 \%)$ & 51 \\
\hline Mishra et al. ${ }^{26}$ & 65 (81.3\%) & $1(1.2 \%)$ & $1(1.2 \%)$ & $10(12.5 \%)$ & $1(1.2 \%)$ & $2(2.5 \%)$ & $0(0.0 \%)$ & 80 \\
\hline $\begin{array}{l}\text { Satia and } \\
\text { Jandhyala }\end{array}$ & $2(3.6 \%)$ & $0(0.0 \%)$ & 13 (23.6\%) & $34(61.8 \%)$ & $2(3.6 \%)$ & $0(0.0 \%)$ & $4(7.2 \%)$ & 55 \\
\hline Dsouza et al. ${ }^{28}$ & $11(21.6 \%)$ & $1(2.0 \%)$ & $28(54.9 \%)$ & $10(19.6 \%)$ & $0(0.0 \%)$ & $0(0.0 \%)$ & $1(2.0 \%)$ & 51 \\
\hline Singh et al. ${ }^{29}$ & $10(12.8 \%)$ & $0(0.0 \%)$ & $20(25.6 \%)$ & 48 (61.5\%) & $0(0.0 \%)$ & $0(0.0 \%)$ & $0(0.0 \%)$ & 78 \\
\hline Nath et al. ${ }^{30}$ & $20(20.0 \%)$ & $0(0.0 \%)$ & 15 (15.0\%) & 49 (49\%) & $5(5.0 \%)$ & $0(0.0 \%)$ & $11(11.0 \%)$ & 100 \\
\hline
\end{tabular}

$\mathrm{PE}$, pre-eclampsia; HELLP, haemolysis elevated liver enzymes and low platelets; AFLP, acute fatty liver of pregnancy

$0-11.8 \%$ ), and hemolytic anemia (mean $=1.7 \%$, median $=0 \%$, range: $0-17.7 \%)$. There were undetected/other causes like druginduced liver dysfunction, hyperemesis gravidarum, malignancy, poisoning, and autoimmune hepatitis in around $5 \%$ of cases ( mean $=6.1 \%$, median $=5.6 \%$, range: $0-23.3 \%$ ).

A similar trend was evident when study-wise causes were discussed. Almost all studies presented that preeclampsia,
HELLP, and viral hepatitis were the commonest causes of hepatic dysfunction during pregnancy (Table 3, Fig. 2). ${ }^{10-30}$

\section{Viral Hepatitis}

Fifteen studies reported the causes of viral hepatitis. Overall, HEV was the commonest cause of viral hepatitis ( mean $=41.1 \%$, median $=45 \%$, range: $4.5-85.7 \%$ ) followed by HBV ( mean $=34.9 \%$; median $=33.3 \%$, 


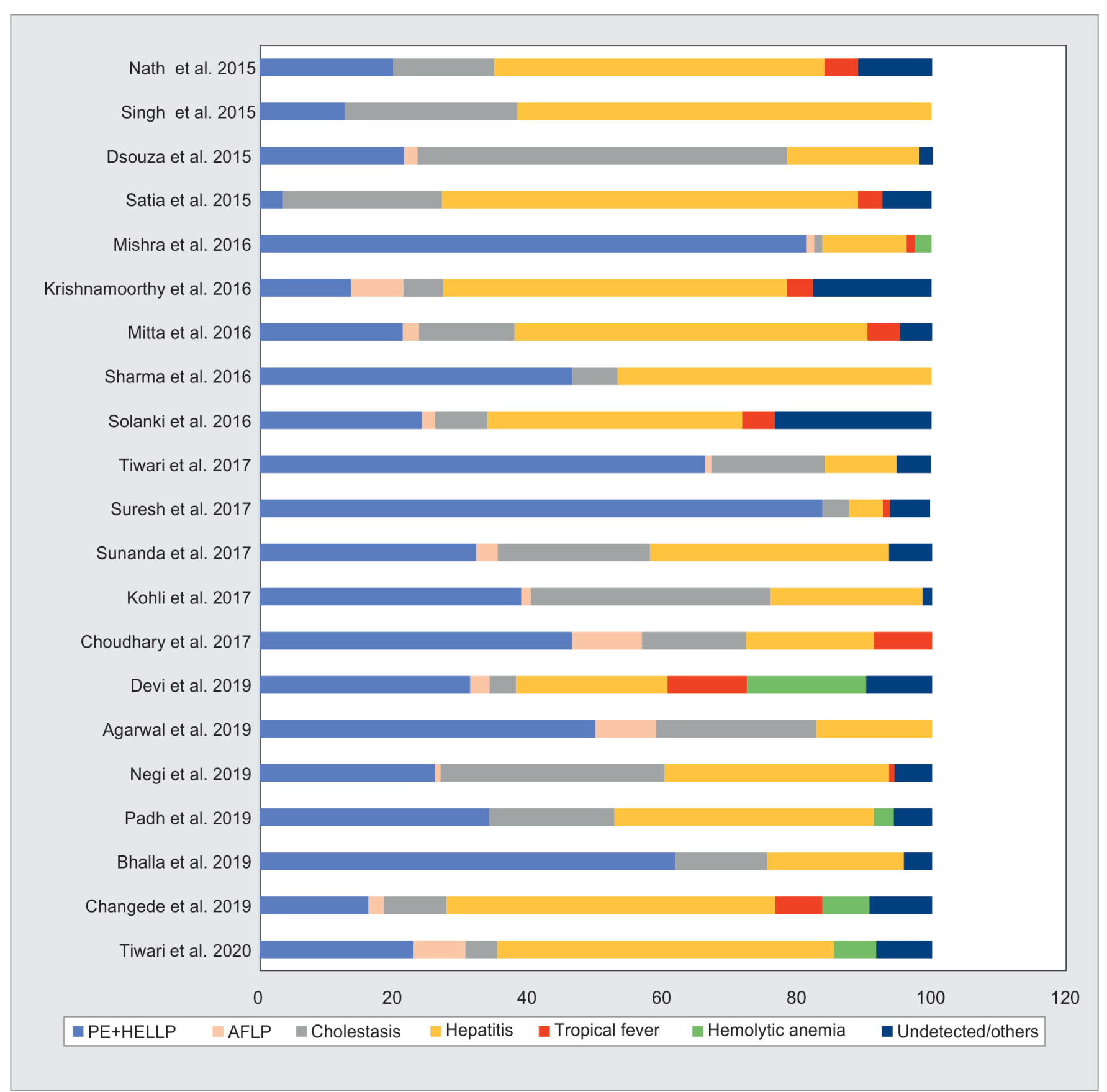

Fig. 2: Causes of hepatic dysfunction in obstetric patients. PE, preeclampsia; HELLP, hemolysis, elevated liver enzymes, low platlets; AFLP, acute fatty liver of pregnancy

range: $0-72 \%$ ) and $\mathrm{HAV}$ (mean $=14.3 \%$, median $=9.5 \%$, range: $0-46.9 \%)$. HCV was reported as a cause of viral hepatitis in only six studies, all of which were from northern India (Lucknow, Varanasi, Moradabad, Faridkot, Ludhiana, and Bhopal) (Fig. 3).

\section{Tropical Fever}

Eleven studies reported the cause of tropical fever leading to hepatic dysfunction in pregnancy. Among the various reasons for tropical fever, malaria was the commonest followed by leptospirosis.

Two studies reported dengue hemorrhagic fever as the cause of hepatic dysfunction, one from Mumbai (one case) and another from Mysore (two cases). ${ }^{20,22}$ Negi et al. reported one case of scrub typhus in his study, including 126 patients from Shimla. ${ }^{14}$

\section{Causes of Maternal Mortality}

Eighteen studies reported the cause of maternal mortality. Viral hepatitis and pregnancy-associated acute liver dysfunction due to preeclampsia, acute fatty liver of pregnancy, and HELLP syndrome were the commonest causes of mortality (Fig. 4). Agarwal et al. from Lucknow reported the maximum deaths due to hepatic encephalopathy, but arterial ammonia levels were not mentioned in the study. ${ }^{15}$ There were no maternal deaths due to intrahepatic cholestasis of pregnancy or hyperemesis gravidarum.

No study reported autopsy findings. Immediate and antecedent causes of maternal mortality were not mentioned separately in any study. 


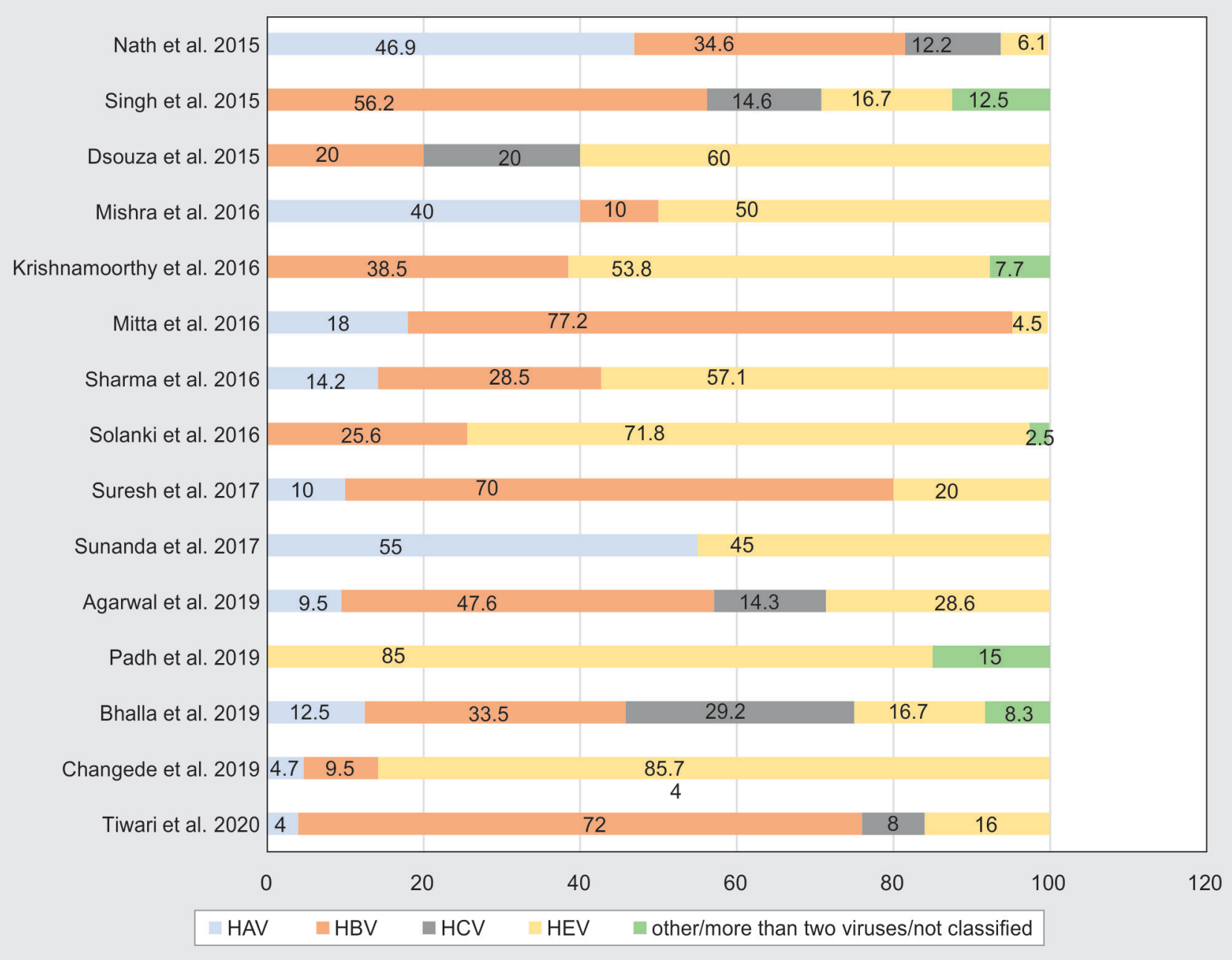

Fig. 3: Causes of hepatitis. HAV, hepatitis A virus; HBV, hepatitis B virus; HCV, hepatitis C virus; HEV, hepatitis E virus

\section{Discussion}

To the best of our knowledge, this is the first systematic review reporting causes of hepatic dysfunction in obstetric patients in India. Our systematic review showed that $70 \%$ of cases of hepatic dysfunction in obstetric patients are either due to preeclampsia/ HELLP or viral hepatitis.

The rate of hepatic dysfunction in obstetric patients in India $(0.15-3.3 \%)$ is comparable to other countries. ${ }^{31,32}$

Ch'ng et al. reported liver dysfunction in $3 \%$ of deliveries in a study from South Whales, United Kingdom. ${ }^{31}$ A population-based study from the United States reported hepatic dysfunction due to causes unique to pregnancy in $0.77 \%$ of pregnant women. Of the five unique diseases of pregnancy that cause hepatic dysfunction, preeclampsia was the commonest (134 cases). It was followed by HELLP syndrome (72 cases), intrahepatic cholestasis of pregnancy ( 26 cases), hyperemesis gravidarum (14 cases), and acute fatty liver of pregnancy (1 case). ${ }^{32}$ Diseases specific to pregnancy are the commonest causes of hepatic dysfunction in western countries, while viral hepatitis and tropical fever with jaundice are important differential diagnoses in developing countries like India. Variation in the incidence of hepatic dysfunction within the country could be due to differences in inclusion criteria as some studies included outdoor and admitted patients while others included admitted patients only. Another reason for the difference in hepatic dysfunction incidence could be the difference in the prevalence of viral hepatitis in different geographical regions and study cohorts.

\section{Limitations}

The current study has some limitations due to the lack of use of standardized definitions and surveillance guidelines. Hepatic dysfunction in pregnancy is an umbrella term. It includes antenatal cases and those who develop hepatic dysfunction in the postnatal period, but very few studies have included the latter subgroup (see Table 1). This leads to underreporting of hepatic dysfunction, especially due to postpartum preeclampsia, postpartum hemorrhage-induced shock liver, and sepsis-induced hepatic dysfunction. Although no study reported liver biopsy findings in any of the patients, 16 studies reported laboratory confirmation of the etiology of hepatic dysfunction. This is also because the primary objective of 16 studies was to study the fetomaternal outcome of hepatic dysfunction in pregnancy, while only five studies aimed at 


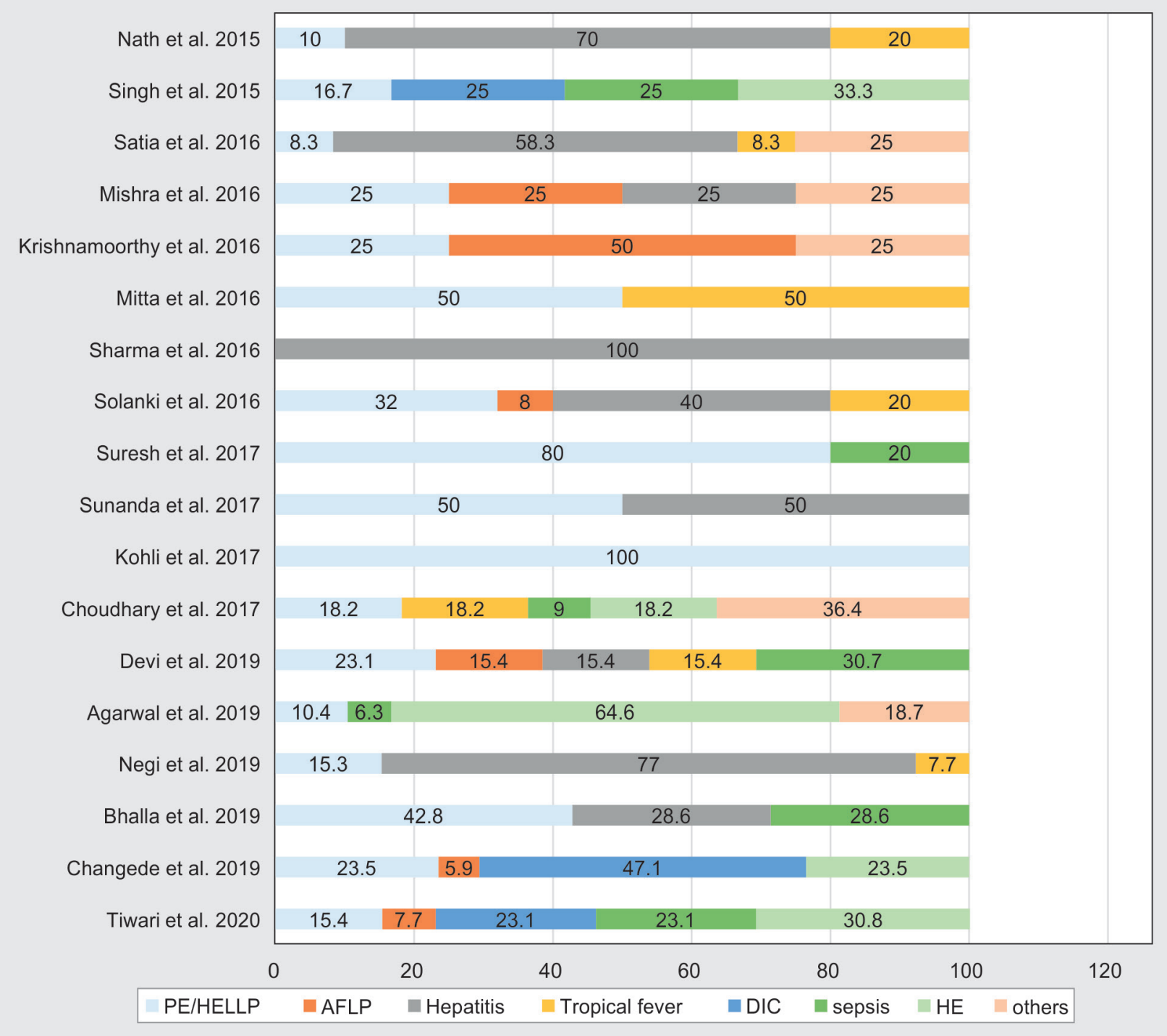

Fig. 4: Causes of maternal mortality. PE, preeclampsia; HELLP, hemolysis, elevated liver enzymes, low platlets; AFLP, acute fatty liver of pregnancy; DIC, disseminated intravascular coagulation; $\mathrm{HE}$, hepatic encephalopathy

investigating the clinical profile, causes, and outcome of hepatic dysfunction in pregnancy.

Another limitation of our study is that we could not classify the causes of maternal mortality appropriately. None of the studies reported immediate, antecedent, and underlying causes of death separately.

It is evident from the current study that reporting of hepatic dysfunction in obstetric patients needs to be streamlined to generate robust data for protocolized care. We suggest using wellaccepted standard definitions/diagnostic criteria for classifying the causes of hepatic definition in pregnancy, e.g., Mississippi criteria for HELLP syndrome, Swansea criteria for acute fatty liver of pregnancy. We also suggest that postpartum patients should be included in the study cohort as sepsis and shock liver are significant differentials in this subgroup.

Besides this, maternal mortality reporting should be done in a standardized format for the correct understanding of the disease burden.

\section{Conclusion}

Currently, moderate-quality evidence shows that hepatic dysfunction in pregnancy in India occurs due to several causes, of which viral hepatitis and preeclampsia/HELLP are the commonest. Mortality may vary depending upon the cause and duration of illness. Hospitals serving large populations from poor socioeconomic backgrounds show higher mortality as patients reach the hospital only late in the course of the disease. A structured national reporting format is needed to find the true epidemiology of hepatic dysfunction in obstetric patients in India. This will help better plan and direct funds in the right direction for ending preventable maternal mortality in one of the world's most populated countries.

\section{HighLightS}

- Hepatic dysfunction in obstetrics is associated with significant fetomaternal morbidity and mortality. 
- It is important to differentiate between causes of hepatic dysfunction in obstetric patients as the treatment and outcome are different.

- There is a moderate quality of evidence to suggest that preeclampsia/HELLP and viral hepatitis are the major causes of hepatic dysfunction in obstetric patients in India.

- Among the various causes of viral hepatitis in obstetric patients in India, HEV hepatitis is the commonest followed by HBV hepatitis.

- There are considerable gaps in the reporting of causes of hepatic dysfunction in obstetric patients in India. A standardized national reporting format is needed to generate robust data and understand the true disease burden.

\section{ORCID}

Armin Ahmed (1) https://orcid.org/0000-0002-1626-7418

Sulekha Saxena @ https://orcid.org/0000-0001-6894-6482

Amita Pandey (1) https://orcid.org/0000-0002-9268-6307

Prabhakar Mishra @ https://orcid.org/0000-0003-4769-9106

Afzal Azim (1) https://orcid.org/0000-0003-3077-5424

\section{References}

1. Strategies toward ending preventable maternal mortality (EPMM). 2015. Available from: https://www.who.int/reproductivehealth/ topics/maternal_perinatal/epmm/en/.

2. Maternal Mortality Rate (MMR). 2021. Available from: https://www. pib.gov.in/PressReleasePage.aspx?PRID=1697441.

3. Girum T, Wasie A. Correlates of maternal mortality in developing countries: an ecological study in 82 countries. Matern Health Neonatol Perinatol 2017;3:19. DOI: 10.1186/s40748-017-0059-8.

4. Arora A, Kumar A, Anand AC, Puri P, Dhiman RK, Acharya SK, et al. Indian National Association for the Study of the Liver-Federation of Obstetric and Gynaecological Societies of India position statement on management of liver diseases in pregnancy. J Clin Exp Hepatol 2019;9(3):383-406. DOI: 10.1016/j.jceh.2019.02.007.

5. Westbrook RH, Dusheiko G, Williamson C. Pregnancy and liver disease. J Hepatol 2016;64(4):933-945. DOI: 10.1016/j.jhep.2015.11.030.

6. Anand AC, Garg HK. Approach to clinical syndrome of jaundice and encephalopathy in tropics. J Clin Exp Hepatol 2015;5(Suppl. 1):S116S130. DOI: 10.1016/j.jceh.2014.05.007.

7. Deepak N A, Patel ND. Differential diagnosis of acute liver failure in India. Ann Hepatol 2006;5(3):150-156. PMID: 17060870.

8. Devarbhavi H, Kremers WK, Dierkhising R, Padmanabhan L. Pregnancy-associated acute liver disease and acute viral hepatitis: differentiation, course, and outcome. J Hepatol 2008;49(6):930-935. DOI: 10.1016/j.jhep.2008.07.030.

9. Denison HJ, Dodds RM, Ntani G, Cooper R, Cooper C, Sayer AA, et al. How to get started with a systematic review in epidemiology: an introductory guide for early career researchers. Arch Public Health 2013;71(1):1-8. DOI: 10.1186/0778-7367-71-21.

10. Tiwari R, Kushwaha P, Meravi A. Analytical study to determine the impact of jaundice in pregnancy on maternal and perinatal outcome. Adv Hum Biol 2020;10(3):153-157. DOI: 10.4103/AlHB.AlHB_63_20.

11. Changede P, Chavan N, Raj N, Gupta P. An observational study to evaluate the maternal and foetal outcomes in pregnancies complicated with jaundice. J Obstet Gynaecol India 2019;69(1):31-36. DOI: 10.1007/s13224-018-1105-9.

12. Bhalla S, Bhatti SG, Kumar S, Kaur P. Predictors of feto-maternal outcome in pregnancies complicated by hepatic dysfunction: observational study in a tertiary care hospital in Punjab. Pan Asian J Obs Gyn 2019;2(1):12-21. Available from: https://journals. indexcopernicus.com/api/file/viewByFileld/674266.pdf.

13. Padh JP, Shah Sr, Vyas RC, Parikh PM. A clinical study on fetomaternal outcome in jaundice with pregnancy. Int J Reprod Contracept Obstet Gynecol 2019;8(10):4079-4082. DOI: 10.18203/2320-1770. ijrcog20194384.
14. Negi LM, Pathania K, Kumar D. Maternal and fetal outcome among pregnant women with jaundice attending a tertiary care institute in northern India. Int J Recent Sci Res 2019;10(4):31793-31796. DOI: 10.24327/IJRSR.

15. Agrawal $M$, Bhanu $M$, Sankhwar $P$, Deo $S$, Jaiswar $S$. A study of spectrum and fetomaternal outcome of jaundice in pregnant women: an experience from a tertiary referral centre of North India. Int J Reprod Contracept Obstet Gynecol 2019;8(7):2838. DOI: 10.18203/2320-1770.ijrcog20193052.

16. Devi KVSMS, Bhavani YVL. A comprehensive study on jaundice in pregnancy with emphasis on fetomaternal outcome. IAIM 2019;6(6): 18-22. Available from: https://iaimjournal.com/wp-content/ uploads/2019/06/iaim_2019_0606_03.pdf

17. Choudhary N, Sen S, Varalakshmi K. A prospective study on pregnancy complicated with jaundice with special emphasis on fetomaternal outcome. Int J Reprod Contracept Obstet Gynecol 2017;6(11):50815088. DOI: 10.18203/2320-1770.ijrcog20175029.

18. Kohli UA, Seth A, Singh S, Mishra R. Liver ailments in pregnancy: our experience Int J Reprod Contracept Obstet Gynecol 2017;6(3):939943. DOI: $10.18203 / 2320-1770$. ijrcog20170560.

19. Sunanda KM, Jois SK, Suresh S. A clinical study of the fetal outcome of jaundice in pregnancy in a tertiary care centre. Indian J Obstet Gynecol Res 2017;4(3):230-234. DOI: 10.18231/2394-2754.2017.0052.

20. Suresh I, Vijaykumar TR, Nandeesh HP. Predictors of fetal and maternal outcome in the crucible of hepatic dysfunction during pregnancy. Gastroenterol Res 2017;10(1):21. DOI: 10.14740/gr787w.

21. Tiwari A, Aditya V, Srivastava R, Gupta G. A study of spectrum and outcome of liver diseases in pregnant women at BRD medical college. Int J Reprod Contracept Obstet Gynecol 2017;6(8):3641-3645. DOI: 10.18203/2320-1770.ijrcog20173501.

22. Solanke D, Rathi C, Pandey V, Patil M, Phadke A, Sawant P. Etiology, clinical profile, and outcome of liver disease in pregnancy with predictors of maternal mortality: a prospective study from Western India. Indian J Gastroenterol 2016;35(6):450-458. DOI: 10.1007/s12664-016-0704-6.

23. Sharma S, Aherwar R, Jawade S. Maternal and fetal outcome in jaundice complicating pregnancy: a prospective study. Int J Reprod Contracept Obstet Gynecol 2016;5(4):1084-1087. DOI: 10.18203/23201770.ijrcog20160862.

24. Mitta P, Rao SV. Fetomaternal outcome in jaundice complicating pregnancy. J Dent Med Sci 2016;15(10):72-76. DOI: 10.9790/08531510067276.

25. Krishnamoorthy J, Murugesan A. Jaundice during pregnancy: maternal and fetal outcome. Int J Reprod Contracept Obstet Gynecol 2016;5(8):2541-2545. DOI: 10.18203/2320-1770.ijrcog20162224.

26. Mishra N, Mishra VN, ThakurP.Study of abnormal liverfunction test during pregnancy in a tertiary care hospital in Chhattisgarh. J Obstet Gynecol India 2016;66(Suppl. 1):129-135. DOI: 10.1007/s13224-015-0830-6.

27. Satia MN, Jandhyala M. A study of fetomaternal outcomes in cases of jaundice at a tertiary care centre. Int J Reprod Contracept Obstet Gynecol 2016;5(7):2352-2357. DOI: 10.18203/2320-1770.ijrcog20162126.

28. Dsouza AS, Gupta G, Sandee SG, Katumalla FS, Goyal S. Maternal and fetal outcome in liver diseases of pregnancy-a tertiary hospital experience. Int J Sci Res Publ 2015;5(9):1-3. Available from: http:// www.ijsrp.org/research-paper-0915.php?rp=P454608.

29. Singh K, Kumar G, Singh A, Rani A. Outcome and management of antenatal patients with jaundice in tertiary care centre of eastern India: a retrospective study. Int J Res Med Sci 2015;3(9):2402-2404. DOI: 10.18203/2320-6012.ijrms20150638.

30. Nath J, Bajpayi G, Sharma R. A clinical study on jaundice in pregnancy with special emphasis on fetomaternal outcome. J Dent Med Sci 2015;14(3):116-119. DOI: 10.9790/0853-1435116119.

31. Ch'ng CL, Morgan M, Hainsworth I, Kingham JG. Prospective study of liver dysfunction in pregnancy in Southwest Wales. Gut 2002;51(6):876-880. DOI: 10.1136/gut.51.6.876.

32. Duraiswamy S, Sheffield JS, Mcintire D, Leveno K, Mayo MJ. Updated etiology and significance of elevated bilirubin during pregnancy: changes parallel shift in demographics and vaccination status. Dig Dis Sci 2017;62(2):517-525. DOI: 10.1007/s10620-016-4282-3. 